\title{
D-commerce- A way for Business
}

\author{
Prof. Dr. V. D. Nandavadekar \\ Director MCA, Sinhgad Institute of \\ Management, Vadgaon Bk, Pune \\ India
}

\author{
Mrs. A. R. Wafgaonkar \\ Lecturer, Hutatma Rajguru \\ Mahavidyalaya, Rajgurunagar \\ Pune India
}

\author{
Dr P V Kulkarni, \\ Asst. Registrar, University of \\ Pune India,
}

\begin{abstract}
With the growth of Internet, digital commerce \& its applications are increasing day by day. D-commerce (DC) is a fast growing technology which is totally based on internet and networking. This research gives insight about DC (Digital commerce) in various fields in the Marketing, Pharmacy, Medicine, Manufacturing, Agriculture, Education, Library, ERP systems and compares its use with other sectors. It focuses on the advantages \& disadvantages and differentiates of DC in the areas mentioned. Due to easy use of applications, more \& more people using it and its new applications are emerging day by day. Increasing competition and demands made by customers worldwide, the rapid pace of change in technology are forcing companies to review the way they do business. What kinds of products and services they offer and the speed with which they release products to a market.

This research paper gives a glimpse of the benefits in the various fields \& how different technologies can be applied to increase profit, reduce errors \& increase efficiency. Technology is strengthening at a tremendous speed and internet has become a vital resource for everyone.
\end{abstract}

\section{Keywords}

D-commerce, Internet, EDI

\section{INTRODUCTION}

DC means buying \& selling of products or services by businesses and consumers over the internet. It is a business environment in which information for buying, selling \& transportation of goods \& services moves electronically. There are three main areas of application of digital commerce. The details are given in table no. 1

About Digital World: can be traced back to the early computers introduced in 1950s. It gained massive popularity following the creation of world wide web. The table no. 2 lists the some of the key events regarding the web, internet \& D-commerce ${ }^{[17]}$. The detail about the growth is given in table no. 2 and use of DC world wide is given table no. 3 .

\section{E-COMMERCE TRADE IN SERVICES}

The General Agreement on Trade in Services (GATS) is another expanded area of trade law. ${ }^{[1]}$ Services are one of the fastestgrowing segment of the world economy, providing more than 60.0 percent of global output and employment. In the past, most services were not considered to be tradable across borders. Advances in communications technology, including the rise of Dcommerce, and regulatory changes have made it easier to deliver services across borders.
Table No. 1 Way of DC

\begin{tabular}{|c|c|c|}
\hline & Type & Details \\
\hline 1 & $\begin{array}{c}\text { Electronic } \\
\text { Markets }\end{array}$ & $\begin{array}{l}\text { It is a perfect market where there are } \\
\text { world wide buyers \& sellers, and its } \\
\text { detailed information about the market. } \\
\text { It refers to trading on the internet. e.g. } \\
\text { online booking system }\end{array}$ \\
\hline 2 & $\begin{array}{c}\text { EDI } \\
\text { (Electronic } \\
\text { Data } \\
\text { Interchange) }\end{array}$ & $\begin{array}{l}\text { Provides standard system for coding } \\
\text { trade transactions that can be } \\
\text { communicated directly from one } \\
\text { computer system to another. It does } \\
\text { not require printed orders or invoices. } \\
\text { It is used in organizations where a } \\
\text { large no of regular transactions occur } \\
\text { regularly. e.g. Malls and supermarket } \\
\text { chains use EDI for transactions with } \\
\text { their suppliers. }\end{array}$ \\
\hline 3 & $\begin{array}{c}\text { Internet } \\
\text { Commerce }\end{array}$ & $\begin{array}{l}\text { Internet allows millions of computers } \\
\text { to be linked together to form a global } \\
\text { network. This type of DC is possible } \\
\text { by the commercial use of internet and } \\
\text { also intranet, It is used to process } \\
\text { online orders to make online payment } \\
\text { to provide after sales service. } \\
\text { e.g. Online banking, internet banking. }\end{array}$ \\
\hline
\end{tabular}

Table No. 2 Growth of IT

\begin{tabular}{|c|l|c|}
\hline & \multicolumn{1}{|c|}{ Growth of IT } & Year \\
\hline 1. & $\begin{array}{l}\text { The first electronic computer, ENIAC was } \\
\text { constructed at University of Pennsylvania }\end{array}$ & 1946 \\
\hline 2. & First satellite "Spuntenic" was launched & 1957 \\
\hline 3. & $\begin{array}{l}\text { US forms the ARPA The advanced } \\
\text { Research Projects Agency with the } \\
\text { department of defence. }\end{array}$ & 1958 \\
\hline 4. & $\begin{array}{l}\text { ARPANET started with four nodes } \\
\text { UCLA, Stanford, UC Santa Barbara \& }\end{array}$ & 1969 \\
\hline University of Utah & $\begin{array}{l}\text { First application of Electronic Data } \\
\text { Interchange }\end{array}$ & 1970 \\
\hline 6. & Introduction of TELNET & 1974 \\
\hline 7. & Internet hosts exceed 10,000 & 1989 \\
\hline 8. & World Wide Web released by CERN & 1992 \\
\hline 9. & $\begin{array}{l}\text { First cyber bank opens, Pizza Hut sales } \\
\text { pizza at internet }\end{array}$ & 1994 \\
\hline 10. & $\begin{array}{l}\text { Inception of business to business D- } \\
\text { commerce }\end{array}$ & 1997 \\
\hline 11. & $\begin{array}{l}\text { Mellisa computer virus is propagated via } \\
\text { e-mail attachments. }\end{array}$ & 1999 \\
\hline 12. & $\begin{array}{l}\text { Internet hosts exceed 200 million, Users } \\
\text { in over 150 countries are connected. }\end{array}$ & 2008 \\
\hline
\end{tabular}


Table No. 3 World Wide DC Growth ${ }^{[13]}$

\begin{tabular}{|l|c|c|c|c|c|c|}
\hline & \multicolumn{3}{|c|}{$\begin{array}{l}\text { Worldwide E-commerce transactions (\$) } \\
\text { 2000 2001 2002 2003 2004 2004 }\end{array}$} & $\begin{array}{l}\text { \% } \\
\text { sales } \\
\text { in } \\
\text { 2004 }\end{array}$ \\
\hline $\begin{array}{l}\text { Total(\$billio } \\
\text { n) }\end{array}$ & 657.0 & 1233.6 & 2231.2 & 3979.7 & 6789.8 & 8.6 \\
\hline $\begin{array}{l}\text { North } \\
\text { America }\end{array}$ & 509.3 & 908.6 & 1498.2 & 2339.0 & 3456.4 & 12.8 \\
\hline United states & 488.7 & 864.1 & 1411.3 & 2187.2 & 3189.0 & 13.8 \\
\hline Canada & 27.4 & 38.0 & 68.0 & 109.6 & 160.3 & 9.2 \\
\hline Mexico & 3.2 & 6.6 & 15.9 & 42.3 & 107.0 & 8.4 \\
\hline Asia Pacific & 53.7 & 117.2 & 286.6 & 724.2 & 1649.8 & 8.0 \\
\hline Japan & 31.9 & 64.4 & 146.8 & 363.6 & 880.3 & 8.4 \\
\hline Australia & 5.6 & 14.0 & 36.9 & 96.7 & 207.6 & 16.4 \\
\hline Korea & 5.6 & 14.1 & 39.3 & 100.5 & 205.7 & 16.4 \\
\hline $\begin{array}{l}\text { Western } \\
\text { Europe }\end{array}$ & 87.4 & 194.8 & 422.1 & 853.3 & 1533.2 & 6.0 \\
\hline Germany & 20.6 & 46.4 & 102.0 & 211.1 & 386.5 & 6.5 \\
\hline UK & 17.2 & 38.5 & 83.2 & 165.6 & 288.8 & 7.1 \\
\hline France & 9.9 & 22.1 & 49.1 & 104.8 & 206.4 & 5.0 \\
\hline Italy & 7.2 & 15.6 & 33.8 & 71.4 & 142.4 & 4.3 \\
\hline Netherlands & 6.5 & 14.4 & 30.7 & 59.5 & 98.3 & 9.2 \\
\hline $\begin{array}{l}\text { Latinn } \\
\text { America }\end{array}$ & 3.6 & 6.8 & 13.7 & 31.8 & 81.8 & 2.4 \\
\hline & & & & & & \\
\hline
\end{tabular}

\section{REVIEW OF LITERATURE}

\subsection{Current Users of DC in India -}

- $\quad$ TATA MOTORS - Managing Supply Chain Management on the Internet India's largest commercial vehicle manufacturer, Tata Motors Company started connecting in 1999, its existing 130 strong dealer network online with the company's

internet based system. It also has plans to bring all its dealers for commercial vehicles and passenger cars on the company's network. Group company Tata Technologies Limited is developing interfaces with its backend ERP systems. The internet based system currently covers the company's manufacturing locations from all over India. It is also negotiating with few banks to establish payment gateways between the value chain at the company - end and the banks. $\left.{ }^{[13}\right]$

- Hindustan Lever - Getting advantage As a part of a internet initiative Hindustan Lever has put in place a network connecting all its suppliers and has launched a pilot project to wire up its 7500 distributors. In the second phase it will attempt mammoth task of connecting its top retailers. Finally it also wants to use the internet for transactions. Lever sees the e-tailing opportunity not only for its own product categories but for a larger universe of products. With its formidable distribution system which covers nearly two million retail outlets. Lever's e-gameplan is to build a number of market leading B2B and B2C businesses in high potential areas $^{[13]}$.

- Financial Institutions Banks -Comprehensive Transactions: ICICI bank is using the internet to acquire more customers by offering them a host of services. Its idea is to become a one stop site where the account holders can do all their money transactions. On other sites one can trade online but all other transactions still have to do physically ICICI offers the entire chain from the Demit account in which a customer's shares are credited to the savings account from which the money is debited to settle the transaction for access. The bank has launched an electronic payment service through its internet banking service. ${ }^{[13]}$ The new payment system will do away any paperwork since the biller will be presenting the bills to the customer through its bank website while the customer will pay through the internet. For this the customers will have to register for an internet banking account with the banks. Thus the bank will be able to target both the B2B and $\mathrm{B} 2 \mathrm{C}$ markets ${ }^{[2]}$.

\section{TRANSACTIONS IN DIGITAL WORLD -} DC payment is done in various ways

4.1 Use of Credit Card - Online credit card is much similar to actual card being used no card impression is taken and no signature is available. When customer wants to purchase he or she adds the item to the merchant's shopping cart When the customer wants for the payment a secure tunnel through the internet is created using SSL (Secure Socket Layer). Using encryption SSL secures the session during which the credit card information will be sent to the merchant and protects the information. Once the consumer credit card information is received the merchant software contacts a clearing house which authenticates credit card and verifies account balances. Clearing house contacts the issuing bank to verify the account information. Once verified the issuing bank credits the account of the merchant's bank The debit to the consumer account is transmitted to the consumer in the monthly statement ${ }^{[14]}$.

4.2 Digital Cash (e-cash) - Digital cash was one of the first forms of alternative payment systems developed for Dcommerce. The early generations of digital cash were quite complex and required the generation of entire new payment industry standards \& practices. First generation digital cash worked as given:- To use e-cash customer had to first establish an account at bank that was using e-cash system. Once the account was established the customer then downloaded digital wallet software on his computer. Then the customer could request a transfer of digital cash. Once the digital wallet had cash the consumer could spend that cash at merchants who were willing to accept it. The software would deduct the cash from the digital wallet and transfer to the merchants. The merchant could then transfer the cash back to the bank to confirm that it has not been double spent. The bank would then cancel the e-coins and credit the merchant's account at the bank. These early concepts were not market successes proving too complicated for both consumers and merchant. One variation on the digital cash concept is gifi cash which is a form of e-cash that is earned as a "points". Two of the best providers of gifi cash are Beenz.com (which issued points as a reward for purchase) and Flooz.com (which could be purchased as a form of gift certificate) both ceased operations in August 2001.Mypoints.com which issues points that can be redeemed for merchandise or gift certificates (but not cash) at partners sites in exchange for viewing ads or trying special offers is still in business as of August 2001. However mypoints.com can be considered a gift cash provider although the primary focus of its efforts is 
developing loyalty programs for clients rather than providing an online currency ${ }^{[14]}$. The way of handling digital cash and its details are given in table no. 4

4.3 ONLINE STORED VALUE SYSTEM: Makes customer pay instantly to merchants and other individuals based on value stored in an online account.

Table No. 4 Digital Cash

\begin{tabular}{|c|c|}
\hline System & Year Founded /description \\
\hline $\begin{array}{l}\text { First } \\
\text { Virtual }\end{array}$ & $\begin{array}{l}1994-1^{\text {st }} \text { secured stored value system } \\
\text { based on credit card pre use deposits and pin } \\
\text { numbers. Ceased operations in } 1998 \text {. }\end{array}$ \\
\hline $\begin{array}{l}\text { Digital } \\
\text { Cash } \\
\text { (e-cash) }\end{array}$ & $\begin{array}{l}1996 \text { Encryption based stored value system } \\
\text { requiring digital wallet on hard drive to } \\
\text { store e-coins. Ceased operations in } 1998 \\
\text { returned as e-cash }\end{array}$ \\
\hline Millicent & $\begin{array}{l}1996 \text { Digital equipment Corporation's entry } \\
\text { into micro payment e-cash. Now a Compaq } \\
\text { platform product with multiple options. }\end{array}$ \\
\hline \multicolumn{2}{|r|}{ Peer to peer payment Systems } \\
\hline Paypal & 1999 free P2P micropayment system \\
\hline $\begin{array}{l}\text { Yahoo } \\
\text { Paydirect }\end{array}$ & 1999. Free Yahoo P2P payment service \\
\hline $\begin{array}{l}\text { Money } \\
\text { Zap }\end{array}$ & $\begin{array}{l}1999 \text { Western Union fee-based money } \\
\text { transfer system }\end{array}$ \\
\hline
\end{tabular}

Some stored value systems require the user to download a digital wallet (for example Monetta's debit service and eCharge's prepaid service) where as others require to simply sign up and transfer money from their existing credit card accounts into an online stored value account. Online stored value systems rely on the value stored in a consumer's bank checking or credit card account. For example Ecount offers a prepaid debit account. To use Ecount a consumer first establish an account with Ecount funded by a credit or debit card. Account information is transferred via the web using SSL. Once Ecount has verified the account and its balance with the consumer's card issuing bank. Consumers can shop on the web where Mastercard is accepted and email payments to individuals. Ecount debits the consumers account and transfers the funds to the merchant or individuals. At the end of the month the consumer's card issuing bank sends a statement showing the debit to Ecount. Rocketcash is another company that offers online stored value system in this case aimed at teenagers ${ }^{[14]}$. Table no. 5 gives detail online stored value system and use of cards.

\subsection{SMART CARDS AS STORED VALUE}

SYSTEM - are another kind of stored value system based on credit cards that have embedded chips that store personal information. Where as credit cards store a single charge account number in the magnetic strip on the back smart cards can hold 100 times more data including multiple credit card numbers and information regarding health insurance transportation personal identification bank accounts and loyalty programs

Table No. 5 Online Stored Value System

\begin{tabular}{|l|l|}
\hline System & Year Founded /Description \\
\hline Ecount & 1998 Prepaid debit account \\
\hline $\begin{array}{l}\text { Monetta } \\
\text { Prepaid }\end{array}$ & $\begin{array}{l}\text { 2000 Prepaid virtual card that allows } \\
\text { consumers to make online payments } \\
\text { without using a credit card or bank } \\
\text { account digital wallet. }\end{array}$ \\
\hline Monetta & 2000 Account that allows users to \\
\hline
\end{tabular}

\begin{tabular}{|l|l|}
\hline Debit & $\begin{array}{l}\text { pay fro m existing checking savings } \\
\text { online of credit accounts Digital } \\
\text { Wallet }\end{array}$ \\
\hline eCharge & $\begin{array}{l}1997 \text { Prepaid account with digital } \\
\text { wallet. }\end{array}$ \\
\hline Millicent & $\begin{array}{l}1998 \text { Prepaid cards purchased at } \\
\text { convenience stores (Japan only) }\end{array}$ \\
\hline \multicolumn{1}{|c|}{ Smart Cards } \\
\hline Mondex & $\begin{array}{l}\text { 1994 smart card stored value system } \\
\text { in which value is stored on a chip on } \\
\text { a card. }\end{array}$ \\
\hline $\begin{array}{l}\text { American } \\
\text { Express } \\
\text { Blue }\end{array}$ & \begin{tabular}{l}
1999 combined credit and smart card \\
\hline
\end{tabular} \\
\hline
\end{tabular}

such as frequent flyer accounts. This capacity makes them an attractive alternative to carrying dozen or so credit and ID card in a physical wallet. Smart cards can also require a password unlike credit cards adding another layer of security. There are two types of smart cards - contact \& contactless depending on the technology embedded. In order for contact cards to be read they must be physically placed into a card reader while contact less cards have an antenna built in that enables transmission of data without direct contact. A stored value smart card such as retail gift card purchased in a certain dollar value is an example of contact card because it must be swiped through a smart card reader in order for payment to be processed. A highway toll payment system such as EZPass is an example of a contactless smart card because the EZPass device in the card is read by a remote sensor with the appropriate toll automatically deduced from the card at the end of the trip. The Mondex card is one of the original smart cards invented in 1990 by Natwest bank in England ${ }^{[14]}$.

4.5 B2B PAYMENT SYSTEMS - Most of the payment are done physically by checks because of the complexity of the $\mathrm{B} 2 \mathrm{~B}$ business. There are two main types of B2B payment systems that have risen to the challenge. Systems that replace traditional banks and existing banking systems extending to the B2B marketplace. No system on the market today yet provides all of the features listed. Actrade is an example of an online B2B payment system that replaces the functionality provided traditionally by banks. Actrade serves as an international marketplace intermediary in the payment process by paying foreign sellers immediately and allowing domestic buyers a variable time a variable time period for repayment ${ }^{[14]}$.

\section{DC TECHNOLOGIES AT OUR DOOR STEP}

Unique identification of products locations and logistic through standard numbering automatic data capture through bar coding and messaging through electronic data interchange (EDI) are the three critical electronic technologies supporting efficient business processes. One can represent any information using standard numbers bar codes and communicate them using electronic means. That in itself will not generate significant benefits to organizations. The real benefits of bar codes standard numbers and electronic data interchange come when information from within and outside the organization is structured in a manner common for all parties. Standard article numbering is an agreed upon universal language for business. It enables different companies to use the same code to mean the same thing. These codes can be represented as bar code symbol for automated data capture or can 
be used in communications especially electronic communications. EAN was established in 1977 to administer a system for the unique identification of products at international level. The article number by itself doesn't carry any information about the entity which is identified. It does not indicate origin the supplier the type or the price of the item. Location codes do not bear any information on the address being identified. The information on what is identified is stored in computer files which are maintained by the trading partners. Article numbers act as an external data key to unlock fixed attributes stored in database about the product.

\section{D-COMMERCE AT GLOBAL}

Marketing and other business Uses -Marketing of any industry can be done on internet using DC technology. For example the hotel industrycan potentially use DC to improve its primary and support marketing management operations by using the new technologies in the value chain. ${ }^{[5]} \mathrm{DC}$ helps in reduce the cost, improve the quality, faster delivery leading to customer satisfaction, efficient buying selling production and for making a decisions at all the level of management.

\section{BENEFITS USING DC}

The benefits of using D-commerce in hotel industry - a) Online reservation is faster and hassle free. b) The internet facilitates the hotel's interaction and helps in the transformation of customerbusiness relationship c) client will save more time by just looking directly into the price list instead of calling over the line d) In click of a button consumers will have a wide choice of products to purchase. e) D-commerce facilitates wide market coverage for products and services. In international hotel operations the presence of websites allows the potentialities of marketing across geographical borders. f) Using DC technology such as the internet promotion of product \& services is more cost \& time efficient by using internet advertising creating consistent brand images worldwide Using internet person can control \& customize the advertisement saving money \& time. Of particular example Hilton Hotel $^{[16]}$ implemented an electronic ticketing scheme through their website in order to make an easier booking of rooms and meeting facilities. For instance Adlon Hotel in Stockholm increased its clientele by maintaining a website that caters to specific international languages such as German French Italian Spanish Portuguese and Scandinavian languages and English. Also the application of multilingual website of Adlon Hotel reduced the amount of advertising using the mainstream media. ${ }^{[4]}$

Search engines on the internet specially focused on the hotel and hospitality sectors are now becoming common. For instance a search engine RezTrip provides a booking solution for hotel websites by using the power of the internet. It claims that its market-centric design results in better conversation ratios(5\%) than other booking engines $(2 \%)$ that are available to the hotels. RezTrip shows that it continues to pitch hotel rooms and ancillary products after the visitor has left the room. It also calculates the amount of time spent on website or number of page views. Virtual Social Networking describes a situation where individuals and organizations are linked by one or more specific types of interdependency i.e. values vision friendship business ideas religion etc. Social networking websites like classmates.com focused on bringing together former school mates \& friends. But later by 2005 business organizations started using social Networking for marketing. Social networks operate under an autonomous business model where members are both suppliers and consumers of information and knowledge. Revenue generation is usually advertisements but when membership and content levels are exclusive and of a high order subscription based revenue is also feasible. According to a 2007 survey by the online Publishers Association $43 \%$ of US online video viewers get videos by clicking links in the e-mail messages from the people they know. According to Business Today -Synovate survey (2008) over 94\% of the corporate executives in India are aware of Virtual Social Networking and $79 \%$ are actually aware of it. "Jupiter Research Online Population Forecast 2006 to 2011: emerging Economies Catalyze Further Growth" report had predicted that the worldwide online population would grow to 1.5 billion in 2006. ${ }^{[5]}$

DC at Supply chain Management: IT has made possible the sharing of large amount of information along the supply chain and is often referred to as essential enabler of supply Chain Management (SCM) activities. Today almost all organizations are in process of adopting some type of e-business technology to streamline SCM activities such as joint forecasting purchasing and collaborative planning. The web is being used for collaborative processes such as collaborative Planning Forecasting and replenishment. In the auto industry supplier firms are using internet features such as e-mail and discussion forums to understand details of the automaker's requirements not completely conveyed in formal documentation. Retailers use the technology to attract customers and enhance sales by use of attractive websites and enabling easy customer search for products. Suppliers use the technology for planning purpose often sale in bulk and may operate under purchasing agreement. Suppliers can use EDI fax or telephone to communicate with manufacturer. ${ }^{[6]}$

\section{DC OPPORTUNITIES ALONG THE SUPPLY CHAIN - PRODUCT/SERVICE DEVELOPMENT Improve product} development by capturing customer input more effectively. Supply Managements: Reduce sourcing cost through increased price transparency and competition. Manufacturing and Assembly: Lower transaction costs by reducing double handling of information. Marketing Strengthen customer relationship and improve cost effectiveness through targeting. Sales and distribution Reduce sales and distribution costs through automation e.g. sales and printed material costs. Customer Improve customer service. E-tailing is online sales of retail style goods. Small business use of the Internet (D-commerce and other applications) has increased from 10 percent in 1996 to about 75 percent today; this use is expected to increase to $85 \%$ within few years. However currently only 28 percent of small companies sell goods and services online. Retailing or "e-tailing" is the most typical B2C activity. They can use the Internet can create their own website to either start a new retailing or service business enhance an ongoing business or provide hardware software or services that allow other businesses to integrate the Internet into their business model. Internet Portals: An organization says a bank or financial institutions generally has a lot of information which is to be sent to the employees on regular intervals. The information could be on some policy strategic decisions change in interest rates leading norms etc. The traditional legacy system of conveying such decisions and information to a large no of geographically scattered locations is fraught with inherent constraints of delay and inconvenience which affects overall efficiency of an organization. The enterprise portal is a single point of contact of community between firms and all stake holders. It organizes information using indexes on visual presentations. An enterprise portal is designed to meet unique demands placed on an 
organization at the network edge. It is a site owned and operated by an organization to support its operation. It facilitates creation of such centralized pool of information at a central repository which can be accessed by the concerned staff through the click of the mouse.

The uses of enterprise portal lie on the following fundamental issues:- 1) improved employee productivity 2) Lower employee support costs 3) Enable sound decision making 4) Create faster decision making cycles 5) Increase employee job satisfaction 6) Improve customer service and enhance customer relationship and loyalty 7) reduce customer service costs 8) Increase sales 9) Improve collaboration with business partners. ${ }^{[9]}$

8.2 E-sourcing : is an act of buying and ordering material through the web. It gives information about what to buy from whom and at what price The process of e-sourcing involves purchases through wide pool of global supplies. Through rapid fire reverse auctions the sourcing costs of corporates have reduced up to $10 \%$. Few live examples include TELCO having reportedly signed a Rs. 1500 Crore e-sourcing deal with free markets the largest sourcing deal in India. TELCO's Rs. 362 Crore pilot project reportedly generated savings of Rs. 22 Crores last year. Seven firms which are part of Pune based corporate have set up India's first private sourcing network. The reverse auctions worth Rs. 50 Crores have resulted in savings of Rs. 7 Crores.

8.3 Medicine - As given by the United States Pharmacopeia Drug Information Volume I for off-label uses there is a popular drug information user edited website called Wikipedia and a traditionally edited pharmacy practice-specific Web site (ie MDR). It is found that while Wikipedia provided factually accurate drug information it was not complete much more likely to contain errors of omission and thus of more limited scope than the information available in MDR as stated

Written information on medicines influences consumer's attitudes toward and use of medications. Thus the use of online drug information resources has the potential to contribute positively to consumers' management of their own health. Healthcare professionals may wish to take a more active role in Wikipedia and may be more inclined to invest their time in wikis that have oversight and formal contributions by fellow practitioners. such as RxWiki (www.rxwiki.com) PubDrug() and MediPedia (www.medipedia.com). [8] Microsoft provides online programs at the San Jose Children's Musical Theatre and University of Washington's Do-IT project to help teens with illness and disabilities stay connected to peers mentors and the rest of the world. Internet access makes a tremendous difference in the lives of children with illnesses and disabilities. It gives them a way to reach out beyond the walls of their isolated environments. They can do research find resources and take advantage of D-commerce without having to leave home. And the Internet also exposes kids to a whole new world of possibilities. Microsoft has understood the very importance of Internet access for these children and has been working to raise awareness of the issue and increase the quantity and quality of technology training initiatives that are available to these young people. The company recently made donations to several organizations that promote technology use for children with illnesses and disabilities. These include the San Jose Children's Musical Theatre (SJCMT) and DO-IT a University of Washington project that uses technology to help children with disabilities reach their cademic and career goals ${ }^{[8]}$

8.4 Pharmacy - Improved productivity which has been made possible by advances in computer software programs and automation technology is leading to more efficient use of pharmacy man and woman power better patient education more effective disease management strategies tighter inventory control and fewer medication errors. As a result there are significant changes in between pharmacists relationships physicians and patients. In short technology is finally moving pharmacy from a profession focused on logistics - the dispensing of drug products - to one in which actual management of the patient's drug regimen is fully realized. This new world of pharmacy technology is divided into D-commerce which covers business-toconsumer (B2C) and business-to-business buying and selling (B2B or e-marketing); automation/robotics; and healthcare Over the Internet.

8.5 D-commerce/B2B - Online networks that connect buyers with sellers distributors with retailers and retailers with manufacturers has the capacity boost the distribution process. Tremendous growth for the e-market/B2B segment is forecast with some D-commerce observers estimating that U.S. B2B sales will reach $\$ 2.7$ trillion by 2004 . One report says $80 \%$ of businesses will be buying products online while $30 \%$ will be sellers. B2B provides the infrastructure to change the things the way supply chains are organized and the way goods and services are exchanged. One B2B company RxBazaar.com is more than a website.RxBazaar.com is open for business 24 hours a day 7 days a week. RxBazaar.com links buyers and sellers of health-related items and offers one stop shopping for short dated and distressed merchandise and overstocks over a secured site. The Internet has spawned a growing and complex healthcare network providing connectivity that enables pharmacists to reach out to suppliers other healthcare providers information resources business data sources and most important the patient/consumer. Schering Report XXII says online pharmacy sales will reach $\$ 20$ to $\$ 25$ billion in 2004 up from $\$ 1.9$ billion in 1999. NCPA reports that it has signed up more than 1000 pharmacies for its Internet retailers. ( cornerDrugstore.com). The popular online pharmacy market is Merckmedco.com which has half of pharmacy Internet sales. According to Merckmedco.com dispenses over 85000 prescriptions a week ${ }^{[9]}$

8.6 Banking \& Finance - D-commerce holds the power to transform banking and financial systems ${ }^{[15]}$. There are three aspects in which D-commerce can affect banking and finance. First banks and financial firms can use the technology and business practice of D-commerce to market their products to the customers. Second D-commerce provides a business opportunity for banks to offer new products and services to serve the needs of D-commerce. Third the new business environment associated with D-commerce provides opportunity for institutional innovations in banking and finance which can help to lay a sounder foundation for the international financial system.

Internet bank and e-brokerage have seen the disappearance of some brick-and-mortar branches of our familiar banks. Low cost convenience and availability are the three main properties of Internet banking. It enables banks and financial companies to offer services with the following qualities: 24-hour seven days-a-week availability convenience fast delivery customer focus and personal service. Time taken in mortgage application is reduced from weeks to hours. The commercial use of the 128-bit encryption opens the way for secure online financial transaction. Banks offering this facility are City Bank ICICI HDFC Global Trust Bank HSBC Union Bank of India State Bank of India and Industrial Bank. City bank was the first to go online with its 
banking services. HSBC has invested to establish itself with online banking to provide its customers with full net capability. In addition private banks like HDFC ICICI and global trust bank have taken a lead in straight online operations.

Second DC represents a business opportunity for banks to offer new products and services to serve the needs of D-commerce. Low cost facility demand has been created by D-commerce for micro payments. Banks can develop services in the areas like: protection for D-commerce participants against fraud electronic billing and assistance for small businesses acting as information intermediary to safeguard the privacy of on-line customers and acting as a rating agency for $\mathrm{D}$-commerce.

Third DC gives an opportunity for re-structuring the banking and financial systems. As the capital market is assuming more and more the role of financing business ventures banks have become less crucial as intermediary between savers and investors. Together with the dangers associated with moral hazard this forms a good reason for governments to withdraw the safety net from banks and set up an independent agency to operate on a totally secure basis the payment and transaction systems. Another potential impact is that central banks may find it more difficult to set interest rates thereby giving up their important function in monetary policy. ${ }^{[2]}$

Venice was a great commercial centre and it was here that banking for the first time separated itself from the changing of money. They evolved to become deposit banks acting as custodians of their clients' money. This proved to be very useful to traders who gradually learned to trust the banks. With traders coming to accept book entry transfers as payment for their merchandise banks acquired the role as payment intermediary between buyers and sellers. Electronic delivery channel of banks includes ATM which is commonly used in bank financial transactions. It is an unattended or unmanned device located on or off the bank's premises. It's function is to receive and dispense cash to handle routine financial transactions. It is made to work 24 hours a day. For this purpose plastic currency and debit cards are used while withdrawing cash from ATM machine. The customer's account number and credit limit are magnetically embedded on a strip of tape on the back of card the operation mechanism is that the card is inserted into ATM the terminal reads and transmits the tape data to a processor which activates the accounts the details are displayed on the screen and by use of keyboard the user can direct the computer to carry out the financial transactions. ${ }^{[15]}$

8.7 Electronic Fund Transfer (EFT) - It is done through electronic data interchange (EDI). But this system involves only minimum amount of data interchange between two parties. There are 3 major electronic fund transfer networks -

these are - Clearing house interbank payment system (CHIPS), Fed wire, Society for world wide interbank financial telecommunication (SWIFT).

These networks transfer million of dollars in each banking day and are capable of handling millions of messages per day. Banks have been using EDI services widely. Banks financial institutions and insurance brokers can use EDI to send messages to the computers of various partners. The Reserve Bank Of India has introduced the electronic fund transfer facility for customers of Indian banks. Under this facility the customer provides the details of the beneficiary account at other centers. In turn customer provides the particulars to the local clearing centre which processes the transactions and will pass on the instructions to the local bank via the bank network to credit the account of the respective beneficiaries. ${ }^{[15]}$
8.8 Computerization in Clearing Houses - In clearing houses also computers are employed to handle cheques The nature of work involved in clearing operations is voluminous repetitive in nature it is complex to clear exchange and settle the transactions among several banks. Computers speed up the process and clearing the operations quickly and efficiently which is voluminous work. Foreign clearing houses managed by the Reserve Bank of India in the major centers like Mumbai Calcutta Chennai Bangalore and New Delhi have been computerized. The new technology is in clearing houses for the purpose of balancing of Reserve Bank's inward and outward clearing cheques. Another use is the preparation of scrolls dealing with receipts and payments transactions on account of government departments. There is a specially designed IT system known as the reader sorter system. It is a powerful IBM system which facilitates cheque sorting and cuts delays in the operation.

8.9 Banking on Home Computers - A separate electronic system bank at home has been designed to facilitate the bank customer to link the bank with that of the user. Banking communication takes place over the telecommunications networks. The lines let the people to interact with their banks. The access to the bank computer takes place by way of phone or the two way cable. TV Banking on the home computer was once considered as a scientific fiction but has now become reality.

8.10 Electronic Money Transfer (EMT) - Transfer of money by electronic means is known as electronic money transfer. It operates by sending money to distant stations through computerized telegraphic network. The stations are connected to the EMT networks stations. The Indian postal department has been adding more stations to the existing one for speedy money order delivery. With the EMT technology the department is able to provide fast data text and money order delivery for the people in remote areas. ${ }^{[15]}$

\subsection{Union's Electronic Money Transfer} (EMT) - The new technology permits quick money transfer of the Union by electric operations. Now it is possible to transfer money from abroad to India within few minutes. It is one-way money transfer service from 75 countries including United States Canada to India. When the sender pays the required cash along with the service fee to any western union agent office the company's computerized network transmits the instructions to a specified western union agent office in India to pay out cash to the denominated recipient within a short time with the money being paid in the recipient can collect cash in rupees at the office of Western Union's agent in this locality. ${ }^{[15]}$

\subsection{Financial Transactions Terminals (FTT) -} In addition to cashless shopping and cyber laundering there are other types of financial transactions Terminals (FTT) in general use. The best instance of the device used is the electronic fund transfer (EFT). Automated teller machine is one of the examples of electronic fund transfer. In banks and other financial institutions financial transactions terminals have been designed to facilitate bank transactions and online terminals are used to handle both deposits and withdrawals of the customers. ${ }^{[15]}$

8.13 E-Cheque - With the development in the field of the information technological techniques the issue of e-cheque is greatly facilitating and has revolutionized the banking business and financial transactions. E-cheque is created on the computer and is processed through the net. In other words it is the electronic version of the paper cheque. The process of issue of and the nature 
of workflow in the issue of e-cheque is the same as the conventional paper cheque. An original e-cheque was developed by the Financial Services Technology Consortium (FSTC) in the US. It is an alliance of 65 financial service providers universities government and IT companies. E-cheque is now established as the main medium of payment. It has legal support and recognition.

\section{PROBLEMS OF SECURITY IN DC}

9.1 Authentication - Banks use the personal identification number (PIN) and a distinct customer identity number which enables customers to access their accounts. This number should not be disclosed to anyone otherwise it will create security problem to anyone.

9.2 Privacy: It is the right of the every account holder to access all financial information. Internet based banking must ensure that only the right person can access this information in order to ensure online privacy state of the art 1024 bit RSA SSL and RCS techniques as well as triple data encryption and standard encryption are used while connecting and communication with bank.

9.3 Integrity: It involves the quality of being honest and appreciating positive work ethics and sincerity in electronic transactions. The whole transaction must satisfy the condition of being whole and authentic.

9.4 Transaction Confirmation / Monitoring: One of the security aspects in internet banking is transaction confirmation or monitoring. This technique involves a list of instructions to be sent to the bank before it goes online and provide a record of all the completed transactions.

9.5 Identification and password: Assigning a correct password ensures the only authorization for data access. Password is the first step of security. If disclosed by the owner will create serious problems to the owner.

9.6 Authorization: One can ensure that only a user can access the data to whom permission has been granted to access read or alter data. Thus a matrix can be created to indicate which users have access to which file. ${ }^{[15]}$

\section{ORGANIZATIONAL/ATTITUDINAL BARRIERS}

Disparate User Community - In order to purchase materials libraries must interact with a very diverse group of partners that includes publishers wholesalers subscription agents and automated library system vendors. As each of these groups has different interests and objectives bringing these groups together to work toward a common goal represents a significant organizational challenge. Without the cooperative efforts of this community it is difficult to attain the support necessary to move toward EDI implementation. Acquisitions is sometimes less a priority than other areas of library operations. Acquisitions is often considered a 'housekeeping' function that may be less a priority than patronoriented services such as reference and circulation. When decisions are made to fund automation projects the acquisitions function has traditionally been given a low priority. This situation may improve has many of the other library processes are now supported by well-developed automated systems. This could help to shift the priority towards automating the acquisitions process. Lack of Education -Education is required on the part of both librarians and members of the book and serial industry. They require a basic understanding of the existing EDI standards and the benefits which can be accrued through EDI implementation.
While progress has been made in this area these efforts must continue.

\section{FINDINGS \& OUTCOMES}

How D-commerce is useful in health care industry as compared with other sectors? D-commerce use is not that popular as compared to education library or any other sector because of the reluctance of the people to use new technology. Many industries are not using the D-commerce technology. Hence even if any industry starts using D-commerce technology the industries related to it must also be using the same technology for the communication. Then only their processes will work and they can save cost \& production time.The topic of e-business and its' utilization in the pharmaceutical industry has emerged as a significant factor for patients doctors and online pharmacies. The operation of e-business has revolutionized communication and has changed the ways hospitals and pharmacies conduct business. From online customer service to remote diagnostics the World Wide Web offers businesses tools that enhance production sales customer satisfaction and profits as a result. In the future perhaps e-business will revolutionize itself so much that prescriptions and medical evaluations will be able to be conducted online through the use of online video portals and the like. ECCRM literature has employed a wide range of research methods constructs and variables and professional activity within the IS research community illustrates its emerging importance Conceptualizing Trust: A Typology and D-commerce Customer Relationships Model assert the need for an interdisciplinary typology of trust to compare and communicate research results more clearly. Improved productivity made possible by advances in computer software programs and automation technology is leading to more efficient use of pharmacy man- and womanpower better patient education more effective disease management strategies tighter inventory control and fewer medication errors. This new world of pharmacy technology can be segmented into D-commerce which covers business-to-consumer (B2C) and business-to-business buying and selling (B2B or e-marketing); automation/robotics; and healthcare over the Internet. Online networks that connect buyers with sellers distributors with retailers and retailers with manufacturers have the potential to streamline the distribution process. The Internet has spawned a growing and complex healthcare network providing unparalleled connectivity that enables pharmacists to reach out to suppliers other healthcare providers information resources business data sources and most important the patient/consumer. A majority of Americans are using the Internet to access health information. According to a survey conducted by Harris Interactive more than half of U.S. adults or 114 million people are using the Internet and of that number $86 \%$ are surfing for health information. That number has almost doubled in the past two years. Most consumers claim to be searching on a regular basis. The data sharing between parties in the supply chain is crucial for carrying out an efficient transition of products. Research and development in information and communication technology made it possible to integrate the supply chains so that the links among Suppliers producers third parties and customers are now easier to be established. The most common technology for establishing electronic links and transmitting messages with short lead times is the Electronic Data Interchange (EDI) defined as the transmission of trade documents electronically using standardized formatting. D-commerce enhances value of the industry through key underlying processes such as high value drug innovation clinical 
development and trial project and people management marketing and sales. The synchronization of D-commerce and corporate strategy has created cogent value for this industry. "Pharmaceutical e-Marketing" which is in reality not a single concept and could be divided into three categories - End user (including doctors and hospitals): This is actually something which is commonly known as "Pharma e-Marketing" but in fact it is only a tip of an iceberg. At this point most mistakes are being made by mixing it up with the rest of the pharmaceutical industry. It is mostly based on providing reports scientific data etc. to the specialists in order to start the promotion of a new drug. A type of the e-Marketing strategy used nowadays is new media. Bulk drugs: This sector is not visible to the end users and mostly involves established drugs like antibiotics antipyretic etc. The competition is getting tougher but is mostly left outside the scope of the e-Marketing. Type of the e-Marketing used-anything from a catalogue on the web to the chemical portals. The usefulness of D-commerce is in various processes of marketing selling manufacturing etc. just like in different sectors like education library etc. which reduces the process cycle time $\&$ cost which will help the industry in future.

\section{CONCLUSIONS}

Increasing competition and demands made by customers worldwide, the rapid pace of change in technology are forcing companies to review the way they do business. The scope of Dcommerce is vast in various sectors and it is growing day by day. Most of the industries are applying DC at maximum level in the organisation. The Financial, manufacturing, processing, service, trading, education and retailers are using and applying various applications of DC. it has required large amount of investment to apply in business. But it is one time investment. The end users and customers are understand the benefits of DC and most of them are using this DC in their daily transaction. As compared to other sectors the DC used very less in health care industry. But the speed is improving now a days. It is rapidly fast growing technology which will take over the whole world in the nearest future. The people should learn the new processes of DC to expand their business world wide and should survive in the competitive world. The security is the major concern to implement and created worries among the various industry and customers. The maintenance cost of the software is very low as compare to the others software. DC helps reduces the trade cycle time in general and total cost of the businesses in particular.

\section{REFERENCES}

[1] Lee K Koivusalo M (2005), Trade and Health: Is the Health Community Ready for Action?, PLoS Med 2(1): e8. doi:10.1371/journal.pmed.0020008

[2] Michael S H Heng, Implications of e-commerce for Banking and Finance research memorandum2001-6 Faculty of Economics Vrije Universiteit Amsterdam
[3] e-commerce Market Research For best designed profit yielding websites.

http://www.wikio.com/article/100737026\#news100737026\#n ews 100737026 Article"

[4] e-commerce and Higher Education - History Types of Virtual Higher-ed Institutions, The Debate over E-learning E-learning worldwide", Free encyclopaedia of E-commerce www.ecommerce.hostif.info,

[5] E-marketing article on "Online Shopping in India", Marketing Mastermind May 2009.

[6] Nada R. Sanders, "The benefits of using e-business Technology: The supplier perspective" Journal of Business Logistics Vol 28 No. 2 - 2007.

[7] "IT in Education", PCQuest Security Risks May 2009

[8] Nicholas C. Romano, Completeness and Accuracy of Drug Information in Wikipedia:, , Jr. IEEE Computer society Washington DCUSA,www.medscape.com

[9] ,HICSS Proceedings of the 34th Annual Hawaii International conference on system sciences(HICSS_34)-Volume 7www.portal.acm.org/toc.cfm

[10] Udayan K. Mandvia, Book titled on Agricultural Marketing and Information Technology, Globalization \& Agricultural Marketing, Excel India

[11] Harish Nair, R. Ramaswami, "e-Commerce Solution Strengthens Customer Service Capabilities for Nordson's, EFDDivision www.theopenpress/forums/index.php?,

[12] Luo R.C., Chih Chin Lan, "The development of WEB based e-commerce platform for rapid prototyping system" Dept. of Electr. Eng. Nat. Chung Cheng Univ. Chia-Yi Taiwan;Research Paper Networking Sensing and Control 2004 IEEE International Conference, 21-23 March 2004Volume: 1 On page(s): 122- 127 Vol.1 (www.Ieeexplorer.ieee.org)

[13]P.T.Joseph, S.J.Chapter, History of E-commerce and Indian Business context E -Commerce An Indian Perspective, Pentice Hall of India Privated Limited, India

[14] Kenneth C., Laudon Carol, Guercio Traver, E-commerce Business Technology Society, Pearson Education New Delhi India

[15] E-Marketing "Online Marketing in the Hospitality Industry", Security Risks PCQuest June 2009 India.

[16] Katherine T Smith, World Wide growth of E-commerce, Supply Chain Globalization E-Business, March 2009 ICFAI University Press India

[17] Patil P.K., Gulwani S.S., Bhise S.S., Information Technology XII Science, Phadke Prakashan Pune India 